А. В. Дорошенко, В. А. Гончаренко, И. Ю. Младенов, А. Н. Цапушел

Одесская национальная академия пищевых технологий, ул. Канатная, 112, Одесса, 65039, Украина

$\triangle$ e-mail: dor_av@i.ua

\title{
РАЗРАБОТКА МНОГОФУНКЦИОНАЛЬНЫХ АБСОРБЦИОННЫХ СОЛНЕЧНЫХ СИСТЕМ НА ОСНОВЕ ТЕПЛОМАССООБМЕННЫХ АППАРАТОВ С ПОДВИЖНОЙ НАСАДКОЙ
}

Разработаны схемные решения тепло-массообменных аппаратов (ТМА) с подвижной псевдоожиженной насадкой (ПН) «газ-жидкоть-твердое тело» для испарительного охлаждения сред (ИО) (испарительные охладители непрямого типа, воды НИОж и воздуха НИОг) и многофункциональных солнечных систем тепло- хладоснабжения и кондиционирования воздуха, основанных на открытом абсорбционном цикле с непрямой регенерацией абсорбента. В осушительном и охладительном контурах солнечных систем используются тепло-массообменные аппараты с подвижной насадкой ПН. Решения для ТМА с ПН «газ-жидкоть-твердое тело» разработаны в нескольких основных вариантах, в частности, с возможностью размещения теплообменника непосредственно в объеме псевдоожиженного слоя насадки (слои насадки ПН и ПНт-к): испарительные охладители НИОг и НИОж охладительного контура солнечных систем; абсорбер-осушитель воздушного потока АБР и десорбер-регенератор ДБР осушительного контура солнечных систем. На основе ичила теоретических и экспериментальных исследований (как для варианта со свободным подвижным псевдоожиженным слоем насадки ПН, так и в варианте с размещением теплообменника непосредственно в объеме псевдоожиженного слоя насадки ПНт-к) и выработанных рекомендаций по определению оптимальных геометрических параметров основных элементов ТМА и режимных параметров, проведен анализ принципиальных возможностей солнечных холодильных СХС и кондиционируюших систем ССКВ, а также сравнительный анализ их энерго-экологических характеристик.

Ключевые слова: Тепло-массообменный апарат; Псевдоожиженный слой насадки; Испарительный охладитель; Охладитель непрямого типа; Абсорбер; Десорбер; Солнечная система; Холодильная система; Система кондиционирования воздуха.

О. В. Дорошенко, В. А. Гончаренко, І. Ю. Младьонов, А. Н. Цапушел

Одеська національна академія харчових технологій, вул. Канатна, 112, Одеса, 65039, Україна

\section{РОЗРОБКА БАГАТОФУНКЦІОНАЛЬНИХ АБСОРБЦІЙНИХ СОНЯЧНИХ СИСТЕМ НА ОСНОВІ ТЕПЛО-МАСООБМІННИХ АПАРАТІВ 3 РУХОМОЮ НАСАДКОЮ}

Розроблено схемні рімення тепло-масообмінних апаратів з рухомою псевдозрідженою насадкою «газрідина-тверде тіло» для випарного охолодження середовищ (випарні охолоджувачі непрямого типу, води НВОр і повітря НВОг) і багатофункціональних сонячних систем тепло- холодопостачання та кондиціювання повітря, заснованих на відкритому абсорбиійному ичиклі з непрямою регенерачією абсорбенту. У осушувальному та охолоджувальному контурах сонячних систем використовуються тепло-масообмінні апарати з рухомою насадкою. Рімення для тепло-масообмінних апаратів з рухомою насадкою «газрідина-тверде тіло» розроблені в декількох основних варіантах, зокрема, з можливістю розміщення теплообмінника безпосередньо всередині псевдозрідженого шару насадки: випарні охолоджувачі НВОг $i$ НВОр охолоджувального контуру сонячних систем; абсорбер-осушувач повітряного потоку АБР $і$ десорбер-регенератор ДБР осушувального контуру сонячних систем. На основі ииклу теоретичних та експериментальних досліджень (як для варіанту з вільним рухомим псевдозрідженим шаром насадки, так $i$ у варіанті з розміщенням теплообмінника безпосередньо в обсязі псевдозрідженого шару насадки) та вироблених рекомендацій щодо визначення оптимальних геометричних параметрів основних елементів тепло-масообмінних апаратів і режимних параметрів, проведено аналіз принцииових можливостей сонячних холодильних систем СХС і систем кондиціювання ССКВ, а також порівняльний аналіз їх енергоекологічних характеристик.

Ключові слова: Тепло-масообмінний апарат; Псевдозріджений шар насадки; Випарний охолоджувач; Охолоджувач непрямого типу; Абсорбер; Десорбер; Сонячна система; Холодильна система; Система кондичіювання повітря.

This work is licensed under the Creative Commons Attribution International License (CC BY). http://creativecommons.org/licenses/by/4.0/ 


\section{ВВЕДЕНИЕ}

Одной из серьезных проблем, характеризующей надежность открытых систем (испарительных водо- и воздухоохладителей) и солнечных теплоиспользующих абсорбционных систем является опасность отложений на рабочих поверхностях тепломассообменной аппаратуры, при работе на водных растворах, жидких сорбентов [1, 7-13]. Накопленный ранее опыт использования трехфазных псевдоожиженных насадочных слоев для организации работы тепломассообменных аппаратов (ТМА) может быть использован для решения этой задачи (аппараты осушительного и охладительного контуров солнечных холодильных систем $\mathrm{CXC}$ и солнечных систем кондиционирования воздуха ССКВ). В работе, наряду с новыми экспериментальными данными, были использованы теоретические и экспериментальные материалы, полученные ранее в Одесской государственной академии холода при создании воздухоохладителей и вентиляторных градирен с подвижной насадкой, а также многолетний опыт инженерной реализации таких аппаратов в энергетических системах, в холодильной технике и системах оборотного водоснабжения [1-6].

\section{I. РАЗРАБОТКА СОЛНЕЧНЫХ МНОГОФУНК- ЦИОНАЛЬНЫХ СИСТЕМ И ТЕПЛОМАСООБ- МЕННЫХ АППАРАТОВ С ПОДВИЖНОЙ НАСАДКОЙ}

Ранее в Одесской государственной академии холода разрабатывались ТМА с подвижной насадкой (ПН) для автономного использования в холодильной технике а также в составе осушительного и охладительного контуров солнечных систем, как аппараты прямого типа с непосредственным контактом взаимодействующих потоков газа и жидкости (ПН): градирни ГПН и воздухоохладители ПИО [10-11]. В настоящем исследовании продолжено развитие этих работ в направлении создания ТМА с ПНт-к непрямого типа [12-13], что существенно расширяет возможности как самих ИО, так и солнечных систем СХС и ССКВ.

Авторами [12] были разработаны испарительные охладители непрямого типа НИОг и НИОж в двух основных вариантах: с размещением подвижного слоя насадки над теплообменником-распределителем воздушных потоков и с непосредственным размещением многоканального теплообменника в объеме подвижной насадки ПНт-к, то есть с расчленением объема псевдоожиженной насадки ПН. Здесь речь идет о режимах псевдоожижения насадочного слоя «газжидкость-твердое тело» в ограниченном объеме, что потребовало специального изучения особенностей основных режимов псевдоожижения. Подвижный слой ПН, обеспечивая интенсификацию процессов тепломасообмена и самоочищаемость рабочих поверхностей, оказывает интенсифицирующее воздействие на процессы тепломасообмена в НИОг и НИОж)

На основе новых решений для ТМА охладительного (НИОг и НИОж) и осушительного (абсорберосушитель АБР и десорбер-регенератор ДБР) конту- ров солнечных систем был разработан ряд новых принципиальных решений для ССКВ (рисунки 1Б и 3Б - для воздухоохладителя регенеративного типа HИО-Rг) и СХC (рисунки 4Б и 5). Обозначения к рисункам 1-5: 1 - десорбер ДБР; 2 - абсорбер АБР; 3 воздухоохладитель НИОг; 4 - воздухоохладитель НИО-Rг; 5 - теплообменник крепкого горячего и слабого холодного растворов абсорбента; 7 - водоохладитель непрямого типа НИОж; П, О и В - полный, основной и вспомогательный воздушные потоки; ВВ - выброс воздуха из ДБР; М, N - крепкий и слабый растворы абсорбента)

\section{II. РАЗРАБОТКА И АНАЛИЗ ХАРАКТЕРИСТИК И ВОЗМОЖНОСТЕЙ АЛЬТЕРНАТИВНЫХ СИС- ТЕМ КОНДИЦИОНИРОВАНИЯ ВОЗДУХА ССКВ}

На рисунках 1-3 (для ССКВ) и 4-6 (для СХC) на $\mathrm{H}-\mathrm{X}$ диаграмме влажного воздуха приведен, на основании полученных экспериментальных результатов по эффективности процессов в основных элементах солнечных систем осушительного и охладительного контуров, общий анализ принципиальных возможностей разработанных солнечных систем в основном для случаев, когда $\mathrm{x}_{\mathrm{g}}^{1}>12,5$ г/кг (для континентального климата характерна именно эта ситуация). Основные базовые решения для солнечных систем с непрямой регенерацией абсорбента приведены на рисунках для анализируемых вариантов ССКВ и СХС. В них, для решения задач кондиционирования воздуха (ССКВ), используется в охладительной части ИО непрямого типа НИОг (НИО-Rг); для СХC используется водоохладитель НИОж.

Рабочие вещества для солнечных абсорбционных систем. Для повышения эффективности процесса испарительного охлаждения в альтернативных системах, атмосферный воздух предварительно осушается в абсорбере. В качестве абсорбентов в открытых системах обычно используются водные растворы хлористого кальция, хлористого лития, бромистого лития, а также многокомпонентные растворы на основе указанных веществ. Раствор хлористого лития $(\mathrm{LiCl})$ получил широкое распространение в качестве абсорбента. Основные его достоинства: бактерицидное действие и безвредность для людей. Воздух, обработанный этим раствором, имеет высокую степень стерилизации - в осушенном воздухе снижение содержания микроорганизмов может достигать 97\%. Для водного раствора $\mathrm{LiCl}$ характерны способность абсорбировать вредные запахи, возможность значительного снижения влагосодержания осушаемого воздуха и широкий диапазон рабочих параметров [1-5]. Недостатком раствора хлористого лития является коррозионное действие на металлы, что требует применения специальных покрытий поверхностей или введения в раствор ингибиторов. Наилучшей поглощающей способностью из перечисленных выше абсорбентов обладает водный раствор бромистого лития ( $\mathrm{LiBr})$. Однако он агрессивен по отношению к металлам и другим материалам и дороже, чем раствор хлористого лития. Раствор бромистого лития получил 

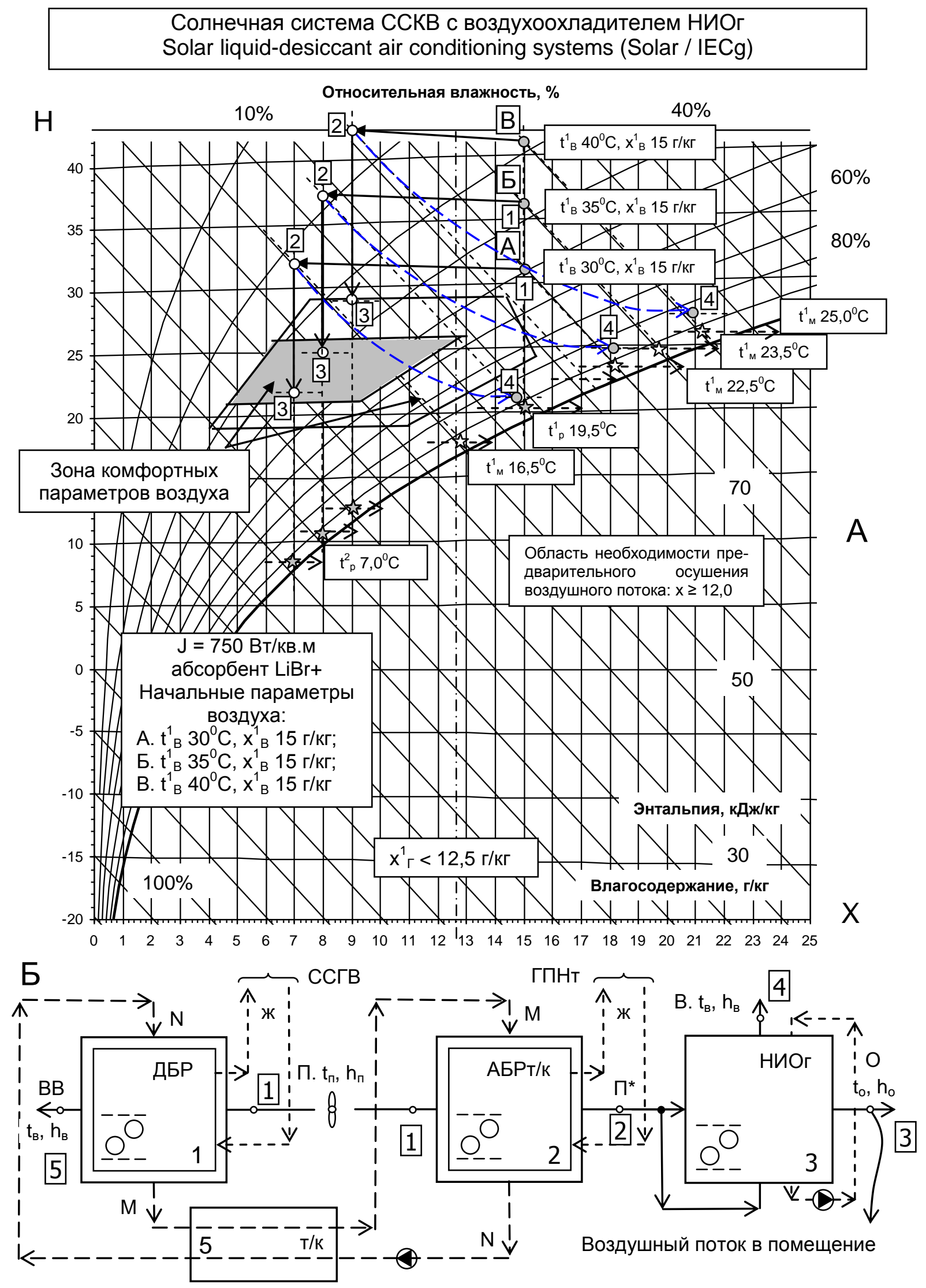

Рисунок 1 - Анализ возможностей солнечной системы кондиционирования воздуха ССКВ; расчетная схема (Б, обозначения в тексте) и протекание процессов на Н-Х диаграмме влажного воздуха (А). Влияние температуры наружного воздуха 

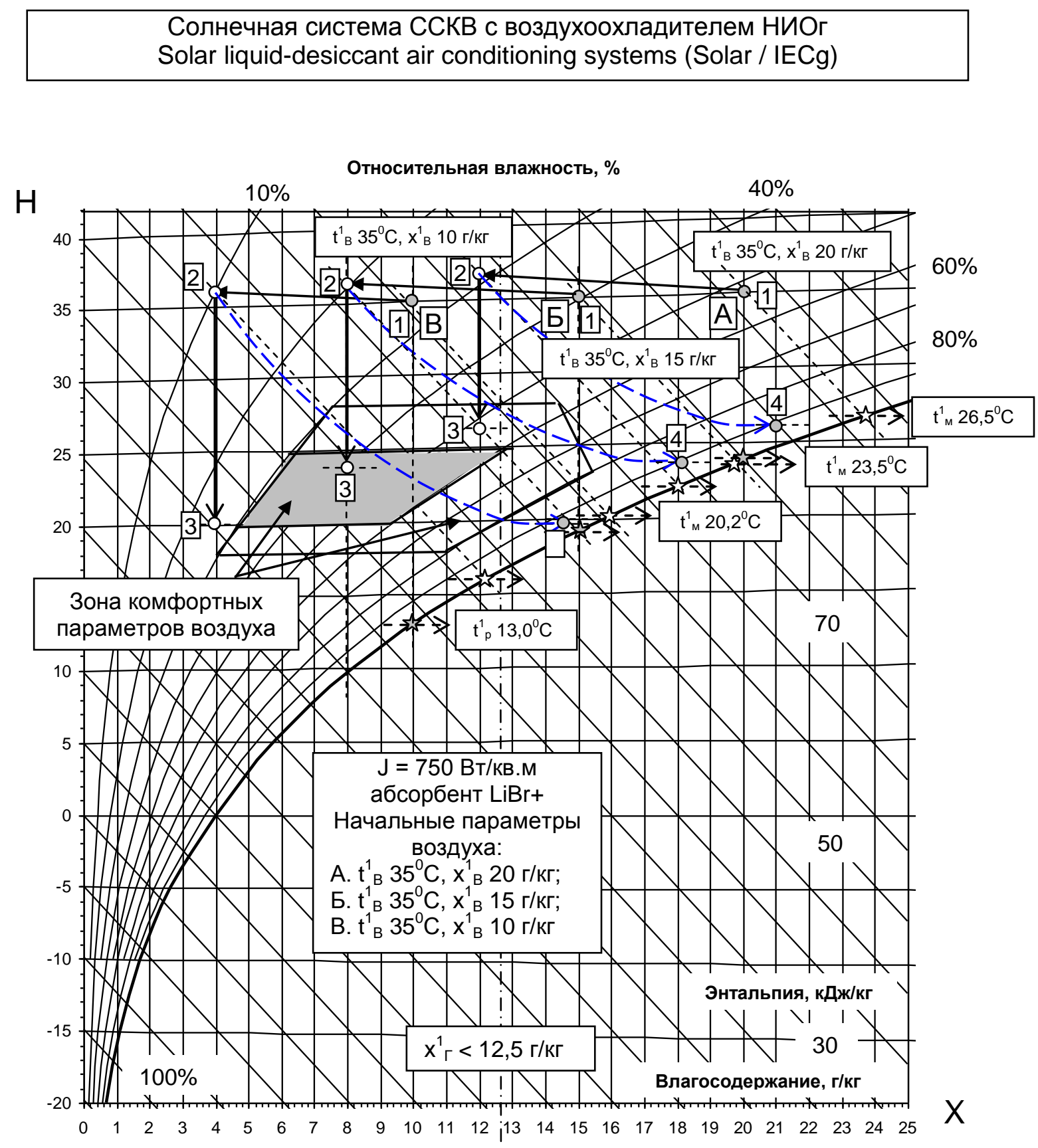

Рисунок 2 - Анализ возможностей солнечной системы кондиционирования воздуха ССКВ; протекание процессов на Н-Х диаграмме влажного воздуха. Влияние влагосодержания наружного воздуха.

Показаны процессы: 1-2 - осушение воздуха в абсорбере АБР; 2-3 - охлаждение основного «О» воздушного потока в НИОг; 2-4 - охлаждение и увлажнение вспомогательного «В» воздушного потока в НИОг 
наибольшее распространение в качестве рабочего тела в закрытых абсорбционных системах. Данные по теплофизическим свойствам раствора в широком диапазоне параметров были получены по расчетным формулам, приведенным в работах [1-2, 8-9]. Для достижения требуемой движущей силы в СХС и ССКВ требуемая концентрация $\mathrm{LiBr}$ должна составлять 60$65 \%$, т.е. линия процесса находится очень близко к линии кристаллизации в интервале температур 30$60^{\circ} \mathrm{C}$. В связи с этим в настоящее время разрабатываются новые многокомпонентные рабочие вещества (композиты), содержащие составляющие, увеличивающие растворимость и снижающие коррозионную активность. В качестве добавок используются $\mathrm{LiNO}_{3}$, $\mathrm{ZnCl}_{2}, \mathrm{CaBr}_{2}$, LiI и другие составляющие. На основании выполненного анализа можно сделать вывод о перспективности использования растворов $\mathrm{LiBr}$ в качестве рабочих веществ в солнечных альтернативных системах; ориентировочно рабочий интервал концентраций этого раствора составляет 60-65\%.

Анализ основных вариантов ССКВ. На рисунках 1-3, на основании полученных результатов по эффективности процессов в основных элементах солнечных систем, приведен анализ принципиальных возможностей разработанных ССКВ (формула ДБРАБР-НИОг) в зависимости от начальных параметров наружного воздуха: его температуры $\mathrm{t}^{1}{ }_{\mathrm{B}}=30,35$ и $40^{0} \mathrm{C}$, при $\mathrm{x}_{\mathrm{B}}^{1}=15$ г/кг (рис. 1) и влагосодержания $\mathrm{x}_{\mathrm{B}}^{1}$ $=10,15$ и 20 г/кг, при $\mathrm{t}_{\mathrm{B}}^{1}=35^{0} \mathrm{C}$ (рисунок 2). Процессы, протекающие в основных элементах систем показаны на Н-Х диаграмме влажного воздуха: 1-2 - осушение воздуха в абсорбере АБР; 2-3 - охлаждение основного «О» и 2-4 - охлаждение и увлажнение вспомогательного «В» воздушных потоков в НИОг. Эти условия охватывают всю территорию Европы, и существенно превышают предельные величины влагосодержания и температуры для Украины. Можно сделать выводы: влияние начальной температуры воздуха на входе в ССКВ при $x_{\text {B }}^{1} 15$ г/кг (рис. 1):

$$
\begin{aligned}
& \text { A. } \mathrm{t}^{1}{ }_{\mathrm{B}} 30^{0} \mathrm{C}, \Delta \mathrm{x}=8,0 \Gamma / \kappa \Gamma, \mathrm{t}_{\mathrm{O}}=21^{0} \mathrm{C}, \mathrm{t}_{\mathrm{B}}=20^{0} \mathrm{C} ; \\
& \text { Б. } \mathrm{t}^{1}{ }_{\mathrm{B}} 35^{0} \mathrm{C}, \Delta \mathrm{x}=7,0 \Gamma / \kappa \Gamma, \mathrm{t}_{\mathrm{O}}=24^{0} \mathrm{C}, \mathrm{t}_{\mathrm{B}}=23^{0} \mathrm{C} ; \\
& \text { В. } \mathrm{t}_{\mathrm{B}}^{1} 40^{0} \mathrm{C}, \Delta \mathrm{x}=6,0 \text { г/кг, } \mathrm{t}_{\mathrm{O}}=27.7^{0} \mathrm{C}, \mathrm{t}_{\mathrm{B}}=26,8^{0} \mathrm{C} ;
\end{aligned}
$$

Эффективность охлаждения воздушного потока Ео в среднем составляет 0,7, несколько снижаясь с понижением начальной температуры $t_{\Gamma}^{1}$; одновременно возрастает и степень осушения воздушного потока. Влияние начального влагосодержания воздуха на входе в ССКВ при $\mathrm{t}_{\mathrm{B}}^{1} 35^{\circ} \mathrm{C}$ (рисунок 2):

$$
\begin{aligned}
& \text { A. } x^{1}{ }_{\mathrm{B}} 10 \Gamma / \kappa \Gamma, \Delta \mathrm{x}=6,0 \Gamma / \kappa \Gamma, \mathrm{t}_{\mathrm{O}}=20^{0} \mathrm{C}, \mathrm{t}_{\mathrm{B}}=19,5^{0} \mathrm{C} \text {; } \\
& \text { Б. } \mathrm{x}_{\mathrm{B}}^{1} 15 \text { г/кг; } \Delta \mathrm{x}=7,0 \text { г/кг, } \mathrm{t}_{\mathrm{O}}=24^{0} \mathrm{C}, \mathrm{t}_{\mathrm{B}}=23,0^{0} \mathrm{C} \text {; } \\
& \text { В. } \mathrm{x}_{\mathrm{B}}^{1} 20 \text { г/кг, } \Delta \mathrm{x}=8,0 \text { г/кг, } \mathrm{t}_{\mathrm{O}}=26.5^{\circ} \mathrm{C}, \mathrm{t}_{\mathrm{B}}=26,0^{\circ} \mathrm{C} \text {; }
\end{aligned}
$$

Исключая область высоких влагосодержаний и температур наружного воздуха солнечная система ССКВ обеспечивает получение комфортных параметров, при существенной экономии энергии (до 35-40\% сравнительно с традиционной СКВ на основе парокомпрессионного холодильного агрегата. При низких значениях влагосодержания наружного воздуха сте- пень осушения воздуха в абсорбере может быть снижена, либо изменением расхода и концентрации абсорбента, либо увеличением количества обрабатываемого (осушаемого в АБР) воздуха. Это обеспечит поддержание комфортных параметров воздуха в помещении (зона комфортных параметров воздуха показана на диаграмме) и дополнительную экономию энергии. Решение задачи для высоких значений $\mathrm{x}_{\mathrm{B}}^{1}=$ 20 г/кг и $\mathrm{t}^{1}{ }_{\mathrm{B}}=40^{\circ} \mathrm{C}$ (см. рис. 1 и 2) может лежать на дополнительном использовании воздухо-воздушного теплообменника, устанавливаемого между абсорбером АБР и испарительным охладителем НИОг в котором выбросной холодный и увлажненный воздушный поток «В», покидающий НИОг, обеспечит охлаждение осушенного воздуха после абсорбера. Это несколько усложняет систему и увеличивает энергозатраты на движение теплоносителей. Такое решение благоприятно с точки зрения опасности реконденсации влаги и существенного падения эффективности, причем эта опасность значительно возрастает с понижением общего уровня охлаждения [1, 14]. В ряде случаев оптимально использование потенциала рециркуляционного воздушного потока, покидающего кондиционируемое помещение.

На рисунке 3 выполнен анализ сравнительных возможностей ССКВ на основе ИО непрямого типа НИОг и НИО-Rг. В НИО регенеративного типа НИО$\mathrm{R} \Gamma$ разделение воздушного потока на основной «О» («продуктовый») и вспомогательный «В», обеспечивающий тепломасообмен в слое ПН при непосредственном контакте с рециркулирующей водой, происходит после охлаждения полного воздушного потока при его неизменном влагосодержании в «основных» каналах ТМА (см. рисунок ЗБ). Получено $\left(\mathrm{t}^{1}{ }_{\mathrm{B}} 35^{\circ} \mathrm{C}\right.$, $\mathrm{x}^{1}{ }_{\mathrm{B}} 15$ г/кг):

$$
\begin{aligned}
& \text { АБР } \rightarrow \text { НИОг: } \Delta x=7,0 \text { г/кг, } \underline{\mathrm{t}_{\mathrm{O}}}=24^{0} \mathrm{C}, \mathrm{t}_{\mathrm{B}}=23^{0} \mathrm{C} ; \\
& \varphi_{\mathrm{B}}=90 \% ; \\
& \text { АБР } \rightarrow \text { НИО-Rг: } \Delta \mathrm{x}=7,0 \text { г/кг, } \underline{\mathrm{t}}_{\mathrm{O}}=16,5^{0} \mathrm{C}, \\
& \mathrm{t}_{\mathrm{B}}=25,8^{0} \mathrm{C} ; \varphi_{\mathrm{B}}=100 \%
\end{aligned}
$$

Следует подчеркнуть два обстоятельства: сопутствующий схеме с НИО-Rг рост энергозатрат (через каналы для потока «О» здесь прокачивается полный воздушный поток «П»), и опасность «реконденсации» влаги из вспомогательного воздушного потока «В» (процесс $3 *-4 *$ фактически протекает по кривой $\varphi=$ $100 \%$ ), что может существенным образом снизить эффективность процесса.

\section{III. РАЗРАБОТКА И АНАЛИЗ ХАРАКТЕРИСТИК И ВОЗМОЖНОСТЕЙ СОЛНЕЧНЫХ ХОЛО- ДИЛЬНЫХ СИСТЕМ СХС}

Анализ возможностей разработанных СХC приведен на рисунках 4 и 6. Процессы, протекающие в основных элементах систем, показаны на Н-X диаграмме влажного воздуха. На рисунке 4 анализ СХC выполнен для начальных влагосодержаний наружного воздуха 20, 15 и 10 г/кг, при температуре $35^{\circ} \mathrm{C}$. В среднем, величина $\mathrm{X}_{\text {г }}=15$ г/кг характерна для круглогодичной эксплуатации СXC на Украине. 

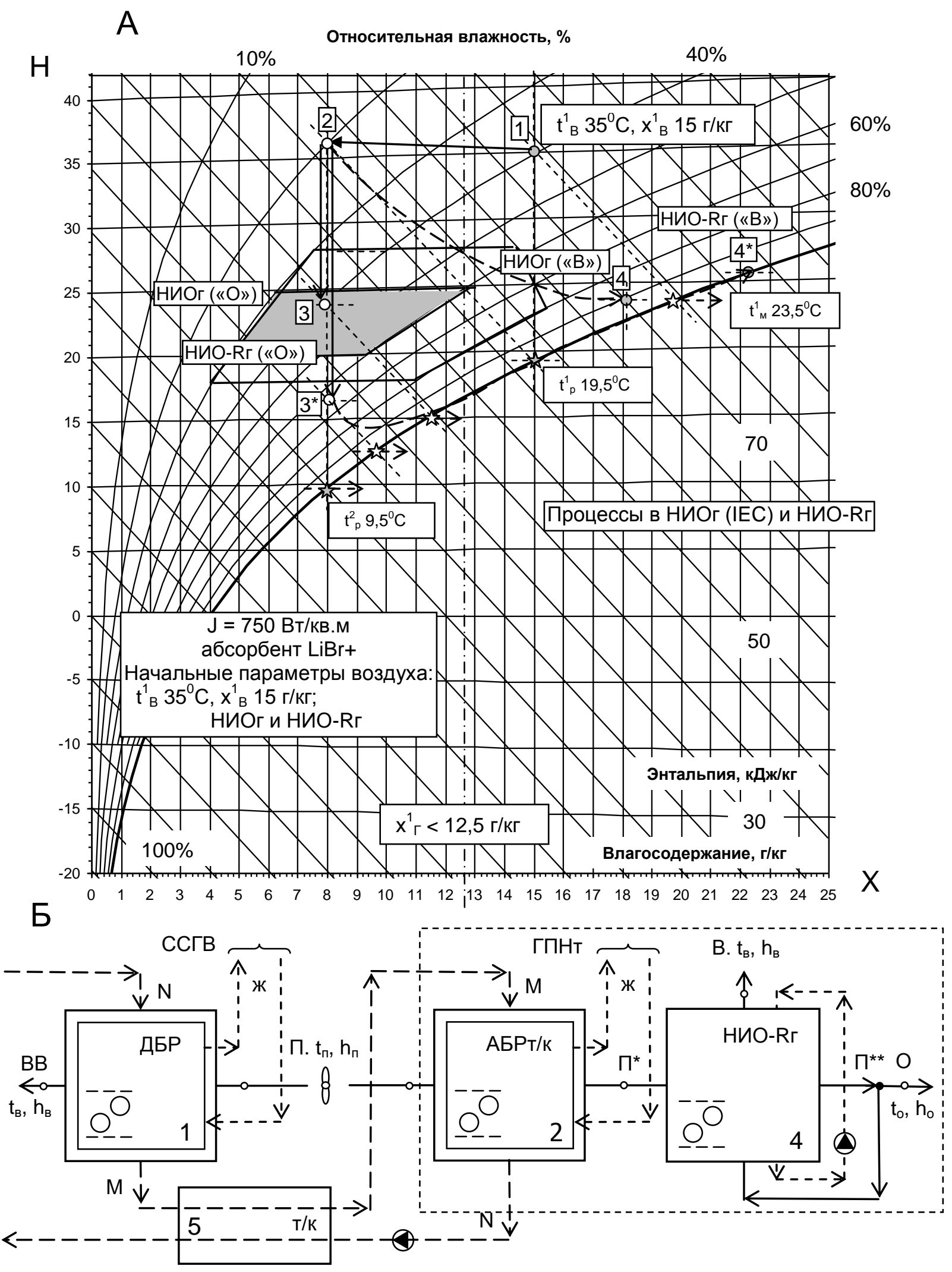

Рисунок 3 - Анализ возможностей солнечной системы кондиционирования воздуха ССКВ; протекание процессов на Н-Х диаграмме влажного воздуха (А). Сравнительные возможности ССКВ на основе НИОг (рисунок 1Б) и НИО-Rг (рисунок ЗБ). Обозначения в тексте статьи 


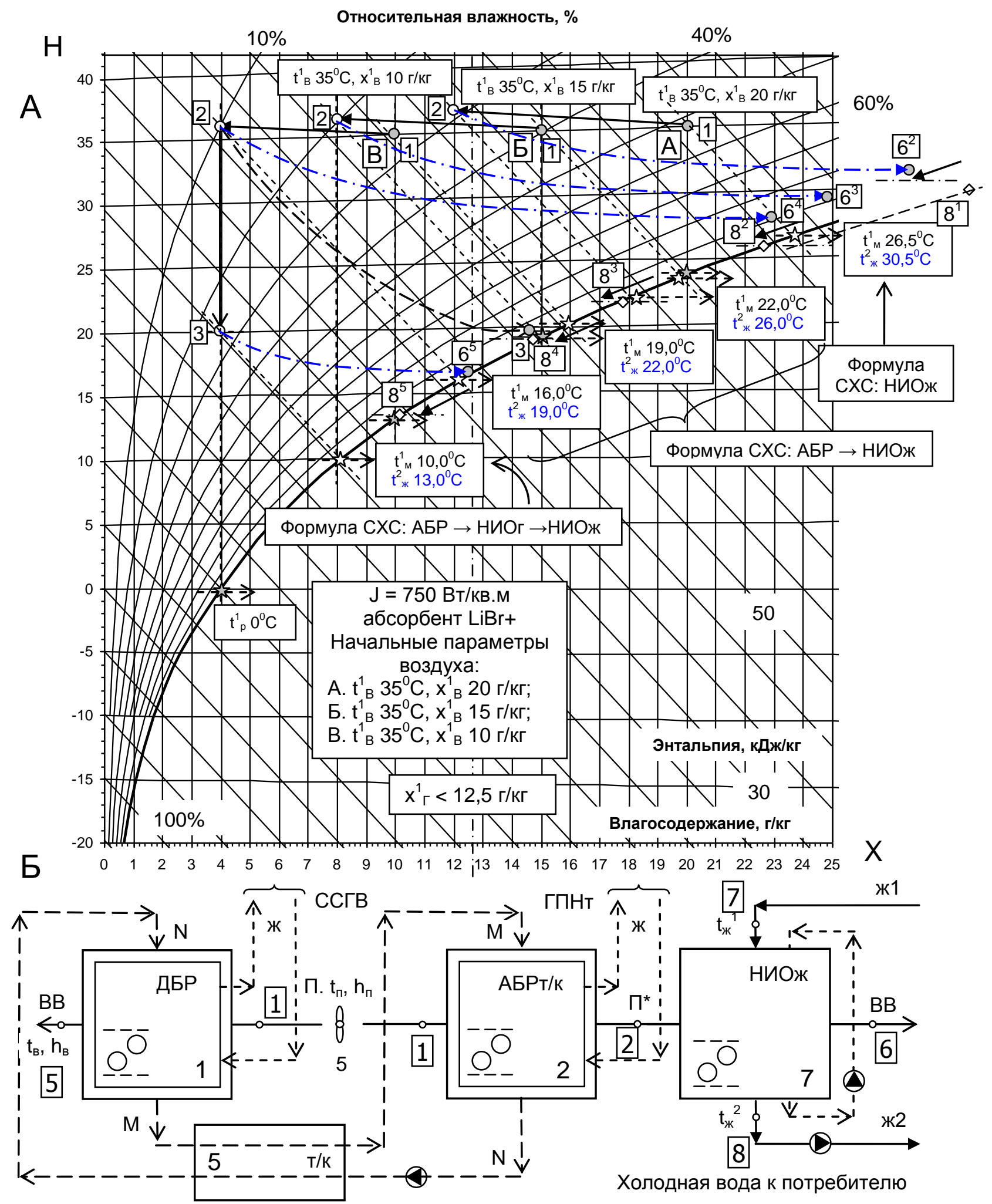

Рисунок 4 - Анализ возможностей солнечной холодильной системы СХС; протекание процессов на $\mathrm{H}-\mathrm{X}$ диаграмме. Принципиальная схема СХC. Влияние влагосодержания наружного воздуха. Обозначения: 1-2 - осушение воздуха; 2-3 - охлаждение основного «О» и вспомогательного «В» воздушных потоков в НИОг; 2-6 - изменение состояния воздушного потока в градирне, в соответствии с вариантами работы СХС $\left(6^{2}-6^{5}\right) ; 8^{1}-8^{2}-8^{3}-8^{4}-8^{5}$ температура охлажденной воды в НИОж, в соответствии со схемой СХС, эти точки показаны условно на $\varphi=100 \%$ ) 
Величина начального влагосодержания воздуха на входе в CXC (при $\mathrm{t}^{1}{ }_{\mathrm{B}} 35^{\circ} \mathrm{C}$ ) оказывает определяющее влияние на эффективность процесса испарительного охлаждения воды в НИОж (рисунок 4). Рассмотрены основные варианты работы СХC:

\section{Формула СХС: НИОж:}

А. $\mathrm{x}_{\mathrm{B}}{ }^{1} 20$ г/кг; $\underline{\mathrm{t}}^{2} \underline{\underline{\text { }}}=30,5^{0} \mathrm{C}$ (при $\left.\mathrm{t}_{\mathrm{m} \mathrm{HB}}^{1}=26,5^{0} \mathrm{C}\right)$.

\section{Формула СХС: АБР $\rightarrow$ НИОж:}

А. $\mathrm{x}_{\mathrm{B}}{ }_{20} 20$ г кг, $\Delta \mathrm{x}=8,0$ г/кг, $\underline{\mathrm{t}}^{2}=26.0^{0} \mathrm{C}$ (точка $8^{2}$, при $\left.\mathrm{t}_{\mathrm{M} \mathrm{HB}}^{1}=26,5^{0} \mathrm{C}\right) ; \mathrm{t}_{\mathrm{BB}}=32,0^{0} \mathrm{C}, \varphi_{\mathrm{BB}}=85 \%$ (точка $6^{2}$ );

Б. $\mathrm{x}_{\mathrm{B}}^{1} 15$ г/кг; $\Delta \mathrm{x}=7,0$ г/кг, $\underline{\mathrm{t}}^{2}=22.0^{0} \mathrm{C}$ (точка $8^{3}$, при $\left.\mathrm{t}_{\text {м НB }}^{1}=24,0^{0} \mathrm{C}\right) ; \mathrm{t}_{\mathrm{BB}}=29,5^{0} \mathrm{C}, \varphi_{\mathrm{BB}}=90 \%$ (точка $6^{3}$ );

B. ${ }^{1}{ }_{\mathrm{B}} 10$ г/кг, $\Delta \mathrm{x}=6,0$ г/кг, $\underline{\mathrm{t}}^{2}=19.0^{0} \mathrm{C}$ (точка $8^{4}$, при $\left.\mathrm{t}^{1}{ }_{\text {м нв }}=20,0^{0} \mathrm{C}, \mathrm{t}_{\mathrm{p}}^{1}=13,0^{0} \mathrm{C}\right) ; \mathrm{t}_{\mathrm{BB}}=27,0^{0} \mathrm{C}, \varphi_{\mathrm{BB}}=$ $95 \%$ (точка $6^{4}$ ).

Дополнительно была рассмотрена СХC по формуле: АБР $\rightarrow$ НИОг $\rightarrow$ НИОж (осушенный в АБР воздушный поток перед поступлением в НИОж охлаждается как основной «О» в НИОг):

$\mathrm{B}^{*} \cdot \mathrm{x}_{\mathrm{B}}^{1} 10$ г/кг, $\Delta \mathrm{x}=6,0$ г/кг; $\mathrm{t}_{\mathrm{O}}=20^{0} \mathrm{C}, \mathrm{t}_{\mathrm{B}}=$ $19,5^{0} \mathrm{C} ; \mathrm{t}^{2}{ }^{2}=13.0^{0} \mathrm{C}$ (точка $8^{5}$, при $\mathrm{t}_{\mathrm{M} \mathrm{HB}}^{1}=20,0^{0} \mathrm{C}, \mathrm{t}_{\mathrm{p}}^{1}=$ $\left.13,0^{0} \mathrm{C}\right) ; \mathrm{t}_{\mathrm{BB}}=16.5^{0} \mathrm{C}, \varphi_{\mathrm{BB}}=100 \%$ (точка $6^{5}$ ).

Солнечная абсорбционная система СХC, решенная по формуле АБР $\rightarrow$ НИОж обеспечивает охлаждение воды ниже температуры наружного воздуха по мокрому термометру, значительно расширяя возможность практического использования методов испарительного охлаждения сред. Последний вариант $\mathrm{CXC} \mathrm{(АБР} \rightarrow$ НИОг $\rightarrow$ НИОж) основан на использовании промежуточного охлаждения воздуха, осушенного в абсорбере перед его поступлением в водоохладитель. Солнечная СХC обеспечивает охлаждение воды в НИОж до точки росы наружного воздуха.

Воздух покидает продуктовую градирню, работающую на низком температурном уровне в состоянии, близком к насыщению и при достаточно низких температурах, что позволяет использовать его для предварительного охлаждения осушенного воздушного потока, покидающего абсорбер. Это позволяет, при той же степени осушения воздуха в АПН, получить дополнительное снижение температуры холодной воды.

Вариант СХC* с охлаждением абсорбера АБР частью охлажденной в НИОж воды приведен на рисунке 6 (с аппаратурным оформлением СХC, рисунок 5). Такое решение позволяет вообще исключить из схемы осушительного контура градирню технологического назначения ГПНт, обслуживающую абсорбер и снизить температурный уровень процесса абсорбции водяных паров, что ведет к повышению эффективности этого процесса. На рис. 6 в поле Н-X диаграммы влажного воздуха показано протекание процессов в рассматриваемом варианте СХС. Сравнение процессов осушения воздуха $1-2$ и $1-2 *$, показывает рост эффективности осушения воздуха и дополнительное расширение глубины зоны охлаждения за счет снижения температуры осушенного воздушного потока (снижается величина $\mathrm{t}^{1}{ }_{\mathrm{M}}$. Для двух сравни- ваемых вариантов (СХC по рисунку 4 и $\mathrm{CXC}^{*}$ по рисунку 5), с обычной формулой АБР $\rightarrow$ НИОж (процесс $1-2$ ) и использованием части охлажденной воды из продуктовой градирни для охлаждения АБР, формула $\mathrm{CXC}^{*}\left(1-2^{*}\right)$ получено $\left(\mathrm{t}_{\mathrm{B}}^{1} 35^{0} \mathrm{C}, \mathrm{x}_{\mathrm{B}}^{1} 10\right.$ г/кг):

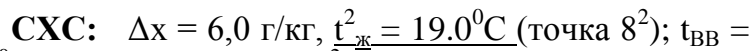
$27,5^{\circ} \mathrm{C}, \varphi_{\mathrm{BB}}=90 \%\left(\right.$ точка $\left.6^{2}\right)$;

CXC $^{*} ; \Delta \mathrm{x}=7,3$ г/кг, $\mathrm{t}^{2}$ ж= $14.5^{0} \mathrm{C}\left(\right.$ точка $\left.8^{2 *}\right) ; \mathrm{t}_{\mathrm{BB}}=$ $26,0^{0} \mathrm{C}, \varphi_{\mathrm{BB}}=95 \%\left(\right.$ точка $\left.6^{2 *}\right)$.

Дополнительно, для условий $\mathrm{t}_{\mathrm{B}}^{1} 30^{0} \mathrm{C}, \mathrm{x}_{\mathrm{B}}^{1} 8$ г/кг для схемы СХC* получено:

$\Delta \mathrm{x}=7,6$ г/кг, $\underline{\mathrm{t}}^{2}=10.0^{0} \mathrm{C}$ (точка $\left.8^{2 * *}\right) ; \mathrm{t}_{\mathrm{BB}}=$ $24,0^{0} \mathrm{C}, \varphi_{\mathrm{BB}}=100 \%$ (точка $\left.6^{2 * *}\right)$

Следует отметить протекание процесса изменения состояния воздуха в НИОж в последнем варианте СХC непосредственно по кривой насыщения, что может приводить к «реконденсации» водяных паров и снижению эффективности.

Основные полученные результаты иллюстрируются на рисунке 7. Видно, как снижение влагосодержания воздуха значительно снижает достигаемую температуру охлажденной воды (рисунок 7А). Из графика на рисунке 7Б следует, что максимальная эффективность охлаждения характерна для варианта CXC*. Следует отметить, что в таком решении снижается производительность СХС по «продуктовой» воде.

\section{IV. СРАВНИТЕЛЬНЫЙ ЭКОЛОГИЧЕСКИЙ АНА- ЛИЗ АЛЬТЕРНАТИВНЫХ СИСТЕМ КОНДИЦИ- ОНИРОВАНИЯ ВОЗДУХА НА ОСНОВЕ ОСУ- ШИТЕЛЬНО-ИСПАРИТЕЛЬНОГО ЦИКЛА}

В работе последовательно выполнялась оценка основных критериев для трех стадий полного жизненного цикла (ПЖЦ) разработанных ССКВ: стадии производства, эксплуатации и утилизации. Выполнение анализа с помощью метода ПЖЦ $[1,5]$ позволяет проанализировать все стадии трех сравниваемых установок, традиционного типа - парокомпрессионной СКВ, и двух альтернативных вариантов ССКВ (таблица 1), учитывая производство материалов системы, хладагента, а также упрощенные производственные процессы при создании обоих СКВ. При анализе не рассматривалась система воздуховодов (система распределения потоков воздуха и воды) в кондиционируемом здании, поскольку для всех сравниваемых систем она идентична.

Анализ уровня выбросов вредных веществ на стадии производства системы основан на полном жизненном цикле материалов, а это означат, что энергозатраты на производство материалов являются суммой энергозатрат на получение, обработку, подготовку и транспортировку соответствующих материалов. Для выполнения анализа необходимо знать виды и массы материалов, из которых изготовлена система. В таблице 1 представлены основные данные по структуре материальных затрат на создание всех трех сравниваемых установок СКВ, массы материалов, а также. 
Таблица 1 - Технические характеристики сравниваемых традиционной СКВ и осушительно-испарительной CCKB

\begin{tabular}{|c|c|c|c|}
\hline \multirow{2}{*}{$\begin{array}{c}\text { Технические характеристики } \\
\text { рассматриваемых систем } \\
\text { (холодопроизводительность состав, } \\
\text { материал, вес) }\end{array}$} & \multirow{2}{*}{$\begin{array}{c}\text { Традиционная } \\
\text { система СКВ } \\
\text { (воздушный кондицио- } \\
\text { нер } C A A E / C A E N-51, \\
\text { производства Фран- } \\
\text { ичии) }\end{array}$} & \multicolumn{2}{|c|}{$\begin{array}{c}\text { Альтернативные солнечные } \\
\text { осушительно-испарительные } \\
\text { ССКВ }\end{array}$} \\
\hline & & $\begin{array}{l}\text { ССКВ на основе } \\
\text { ТМА с ПН слоем } \\
\text { насадки [10-11] }\end{array}$ & $\begin{array}{c}\text { ССКВ на основе } \\
\text { ТМА с ПНт-к } \\
\text { слоем насадки }\end{array}$ \\
\hline Холодопроизводительность, кВт & 14.3 & 14.0 & 14.0 \\
\hline $\begin{array}{l}\text { Компрессор: } \\
\text { Корпус (сталь 45), кг } \\
\text { Провода (медь), кг } \\
\end{array}$ & $\begin{array}{l}45.0 \\
2.3\end{array}$ & - & - \\
\hline $\begin{array}{l}\text { Вентилятор: } \\
\text { Двигатель (сталь 45), кг } \\
\text { Импеллер (алюминий), кг } \\
\text { Провода (медь), кг }\end{array}$ & $\begin{array}{l}6.0 \\
2.0 \\
1.1 \\
\end{array}$ & $\begin{array}{c}3.6 \times 2 \\
2.6 \times 2 \\
2.3\end{array}$ & $\begin{array}{c}3.6 \times 2 \\
2.6 \times 2 \\
2.3 \\
\end{array}$ \\
\hline $\begin{array}{l}\text { Жидкостные насосы: } \\
\text { Двигатель (сталь 45), кг } \\
\text { Провода (медь), кг } \\
\end{array}$ & - & $\begin{array}{l}1.6 \times 2 \\
2.5 \\
\end{array}$ & $\begin{array}{l}1.6 \times 2 \\
2.5 \\
\end{array}$ \\
\hline $\begin{array}{l}\text { Воздушный конденсатор ХМ: Корпус (сталь } \\
45), \text { кг } \\
\text { Рёбра (алюминий), кг } \\
\text { Трубки (медь), кг }\end{array}$ & $\begin{array}{l}6.9 \\
9.0 \\
9.3 \\
\end{array}$ & - & - \\
\hline $\begin{array}{l}\text { Воздухоохладитель (испаритель) ХМ: } \\
\text { Корпус (сталь 45), кг } \\
\text { Рёбра (алюминий), кг } \\
\text { Трубки (медь), кг } \\
\text { Хладагент (R22), кг } \\
\end{array}$ & $\begin{array}{l}5.4 \\
7.9 \\
8.6 \\
4.0\end{array}$ & - & - \\
\hline $\begin{array}{l}\text { Осушитель воздуха: } \\
\text { Корпус (сталь 45), кг } \\
\text { Алюминий, кг } \\
\text { Медь, кг }\end{array}$ & $\begin{array}{l}1.5 \\
3.7 \\
4.0 \\
\end{array}$ & - & - \\
\hline $\begin{array}{l}\text { Парогенератор } \\
\text { (нержавеющая сталь), кг }\end{array}$ & 20.0 & - & - \\
\hline Фильтр, рамка, элементы фильтра (сталь), кг & 100.5 & 94.2 & 94.2 \\
\hline $\begin{array}{l}\text { Десорбер: } \\
\text { - насадка ПН, кг; } \\
\text { - крепежная рама, кг } \\
\end{array}$ & & $\begin{array}{c}5.5 \\
15.0 \\
\end{array}$ & $\begin{array}{c}6.5 \\
15.0 \\
\end{array}$ \\
\hline $\begin{array}{l}\text { Теплообменник к десорберу (воздушный } \\
\text { поток - горячая вода от ССГВ), кГ }\end{array}$ & & 12.0 & - \\
\hline $\begin{array}{l}\text { Абсорбер: } \\
\text { - насадка ПН, кг; } \\
\text { - крепежная рама, кг }\end{array}$ & - & $\begin{array}{c}5.5 \\
15.0 \\
\end{array}$ & $\begin{array}{c}6.5 \\
15.0 \\
\end{array}$ \\
\hline $\begin{array}{l}\text { Теплообменник к абсорберу (воздушный } \\
\text { поток - холодная вода от ГПНт), кг }\end{array}$ & & 12.0 & - \\
\hline $\begin{array}{l}\text { НИО: } \\
\text { - насадка ПН, кг; } \\
\text { - крепежная рама, кг } \\
\end{array}$ & - & $\begin{array}{l}4.0 \\
2.0 \\
\end{array}$ & $\begin{array}{c}\text { (НИОг) } \\
4.0 \\
2.0 \\
\end{array}$ \\
\hline $\begin{array}{l}\text { Градирня ГПНт: } \\
\text { - насадка ПН, кг; } \\
\text { - крепежная рама, кг }\end{array}$ & - & $\begin{array}{c}5.0 \\
12.5\end{array}$ & $\begin{array}{c}5.0 \\
12.5\end{array}$ \\
\hline $\begin{array}{l}\text { Теплообменники жидкость-жидкость, медь } \\
\text { (2 шт.), кг }\end{array}$ & - & $15 \times 2$ & $15 \times 2$ \\
\hline Солнечные жидкостные коллекторы, кг & - & $\begin{array}{lr}\text { десять } & \text { СКж, } \\
\text { площадью } & \text { каж- } \\
\text { дый в } 2.0 & \text { кв.м., } \\
70 \text { кг } & \\
\end{array}$ & $\begin{array}{lr}\text { десять } & \text { СКж, } \\
\text { площадью } & \text { каж- } \\
\text { дый в } 2.0 & \text { кв.м., } \\
70 \text { кг } & \end{array}$ \\
\hline Общий вес & 251.5 & 284.6 .6 & 260.0 \\
\hline
\end{tabular}



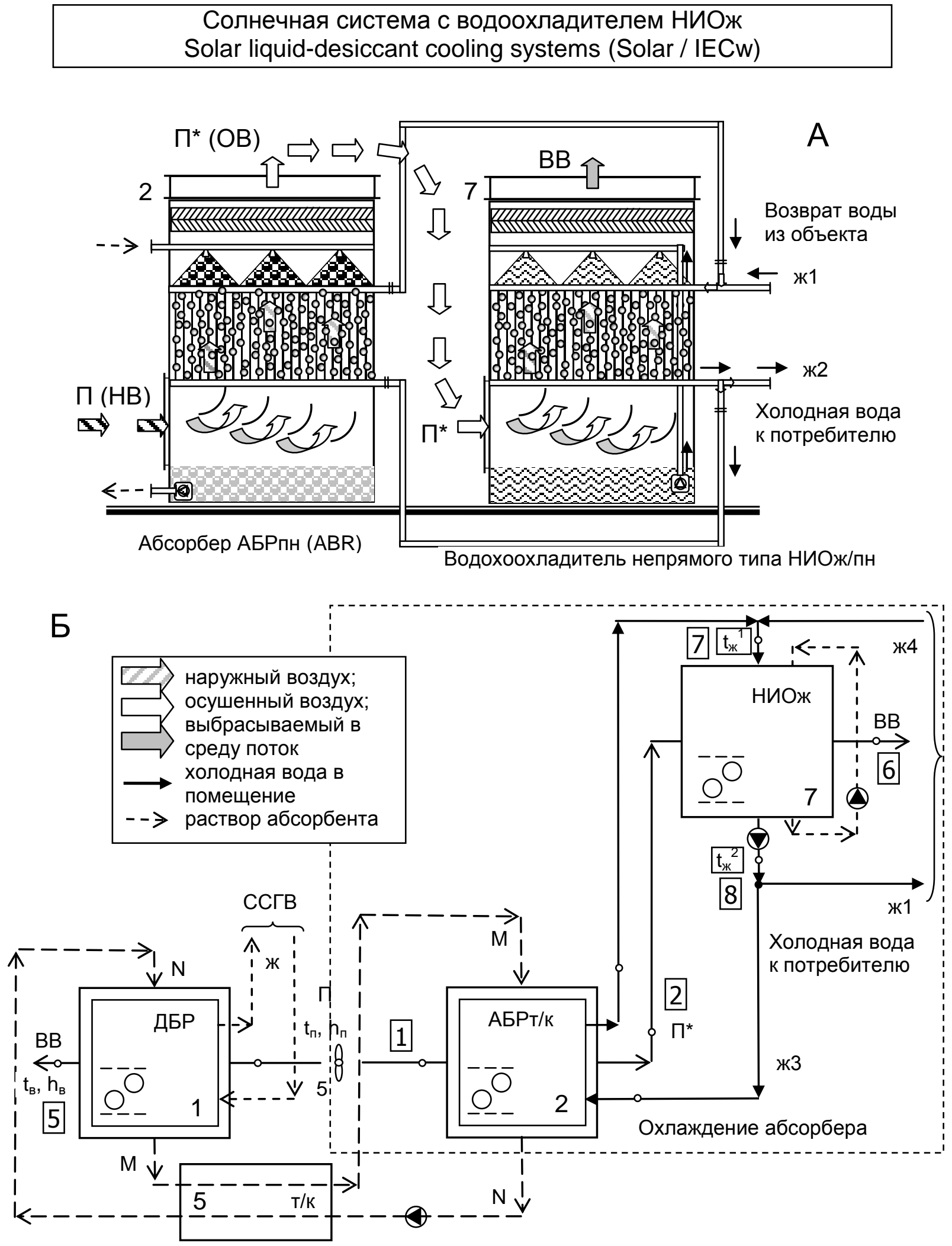

Рисунок 5 - Принципиальная схема солнечной абсорбционной системы с водоохладителем непрямого типа НИОж (7) в охладительном контуре (формула ДБР-АБР-НИОж); охлаждение абсорбера обеспечивает часть охлажденной в НИОж воды. Обозначения приведены в тексте 


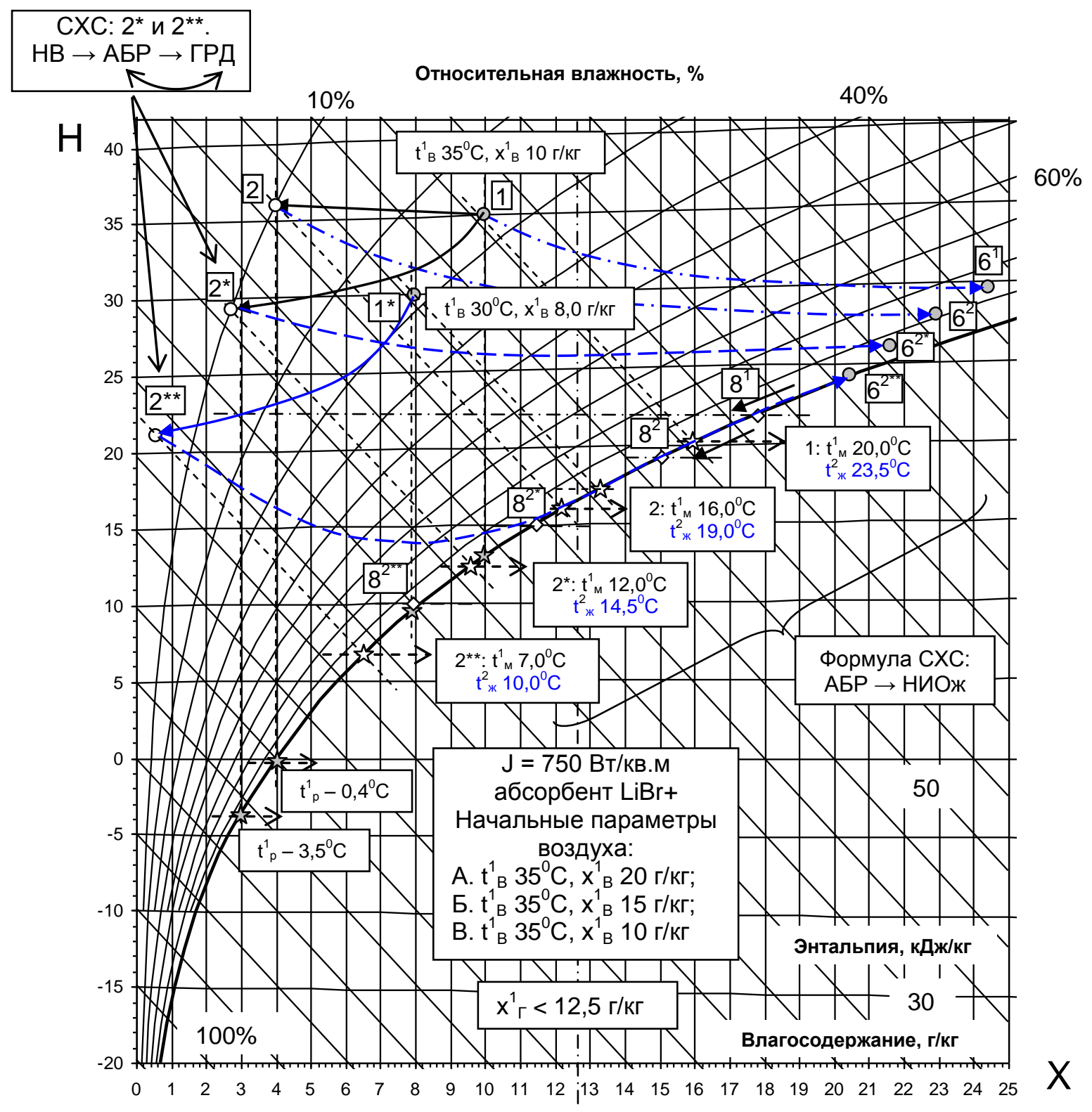

Рисунок 6 - Анализ возможностей солнечной холодильной системы СХС (принц. схема СХС приведена на рисунке 5Б. Охлаждение абсорбера обеспечивает часть охлажденной в НИОж воды); протекание процессов на Н-Х диаграмме.

Обозначения: 1-2 - осушение воздуха; 2-6 - изменение состояния воздушного потока в градирне, в соответствии с вариантом работы СХC; $8^{1}-8^{2}-8^{2^{*}}-$ температура охлажденной воды в НИОж, в соответствии с рассматриваемой схемой СХC 
мощности компрессора, вентилятора и водяного насоca.

Для сравнения был взят крышный кондиционер французского производства CAAE/CAEN - 51, так чтобы холодопроизводительность у сравниваемых вариантов СКВ была примерно одинаковой (14.0 кВт). Материалы, из которых состоят рассматриваемые системы, производятся в различных странах. Получить надежные данные по затратам на производство энергии и эмиссии вредных веществ в различных процессах в разных странах достаточно проблематично. Поэтому, при выполнении анализа, использовались данные по выбросам в разных процессах, как средние для стран Евросоюза (они представлены в программе "SIMAPRO-6", с использованием которой и выполнялся анализ). Так как основной целью работы является сравнение СКВ традиционного и альтернативных типов, то принятое допущение не скажется на качестве анализа и правильности сделанных выводов. Это означает, что, несмотря на реальную структуру производства электроэнергии в стране производителе конкретных материалов, при выполнении анализа учитывались вредные выбросы, соответствующие производству энергии в странах Евросоюза. Выбросы при повторном использовании и утилизации материалов принимались такими же, как в среднем по странам ЕС.

Стадия производства сравниваемых СКВ и ССКВ. В стадии производства учитывается влияние следующих процессов: добычи сырья (включая добычу нефти и газа для производства пластмасс); металлов; производства материалов (например, пластмасс для изготовления насадки ТМА); производства различных деталей СКВ, их сборки и транспортировки. Следует отметить, что, согласно методологии ПЖЦ, в данную стадию включено и повторное использование металлов. В модели принято, что 50 \% стали, $40 \%$ меди и $30 \%$ алюминия произведено из металлолома (это соответствует средним данными по повторному использованию материалов в ЕС). На рисунке 8А представлены основные результаты анализа. Расчет вредного воздействия оценивался с использованием базы данных программы SIMAPRO-6 с учетом расхода энергии на изготовление установки из различных материалов (металлов, пластиков) и на производство хладагента (R22). Как видно из результатов анализа стадии создания оборудования, по всем категориям экологического воздействия традиционная СКВ уступает обоим вариантам ССКВ. Вариант ССКВ, основанный на использовании насадочных слоев ПНт-к во всех ТМА осушительного и охладительного контуров имеет лучшие показатели по основным позициям «Изменение климата» и «Истощение ресурсов».

Стадия эксплуатации сравниваемых систем. На стадии эксплуатации СКВ учитываются энергопотребление систем (с учетом структуры производства электроэнергии в Украине: тепловые электростанции - $49 \%$, атомные электростанции - 43\% и гидроэнергетика $-8 \%$ ) и утечек хладагента (принимаем утечки хладагента 3\% от его общей массы в год для парокомпрессионной СКВ). Потребления электроэнергии компрессором, вентилятором и водяным насосом за время эксплуатации СКВ количественно определены с использованием термодинамических вычислений с учетом профиля нагрузки за сутки (при вычислении величины этой нагрузки предполагалось, что минимальная суточная производительность СКВ - 20\% в рабочем режиме). Используя данные по климатическим условиям для Одесского региона в течение года, установленную холодопроизводительность для каждой СКВ, и, принимая, что средняя продолжительность эксплуатации рассматриваемых СКВ одинакова и равна 10 годам, был проведен анализ периода эксплуатации СКВ (рисунок 8Б), показавший, что по всем трем категориям экологического воздействия традиционная СКВ так же уступает альтернативной. Здесь разница еще более существенна, чем для периода производства рассматриваемых систем. Вариант ССКВ, основанный на использовании насадочных слоев ПНт-к во всех ТМА осушительного и охладительного контуров имеет лучшие показатели по основным позициям «Изменение климата» и «Истощение ресурсов».

Стадия утилизации СКВ. Предполагается, что после окончания срока эксплуатации СКВ демонтируется и направляется на утилизацию. Металлические детали отправляются на повторное использование, а хладагент под давлением извлекается и транспортируется на утилизацию (например, его разрушают пиролизом с получением в качестве конечного продукта веществ, содержащих аргон, диоксид углерода и водяной пар). При оценке влияния этой стадии на общее экологическое воздействие учитывалась также транспортировка (на расстояние 100 км для металлолома и 300 км для утилизации хладагента, - это усредненные параметры, принятые для ЕС). Как видно из приведенных результатов (рисунок 8В), и на этой стадии преимущества сохраняются за альтернативной системой.

Экологическое воздействие за полный жизненный цикл. Для объективной оценки и окончательных выводов по перспективам применения той или иной альтернативной системы следует оценить экологическое воздействие за полный жизненный цикл. Общее экологическое воздействие для обеих СКВ представлено на рисунке 8Г. Результаты выполненного экологического анализа традиционной и альтернативных систем кондиционирования воздуха позволяют сделать вывод о преимуществе солнечных систем. Как видно из выполненного исследования, осушительно-испарительная система оказывает существенно меньшее вредное воздействие на окружающую среду, чем традиционная по всем сравниваемым категориям.

Альтернативная система ССКВ приводит к меньшему истощению природных ресурсов (в т.ч. и энергоресурсов), что говорит о ее большей энергетической эффективности и вносит меньший вклад в глобальное изменение климата. Следует отметить, что высокая энергоэффективность и низкий вклад в глобальное потепление напрямую связаны друг с другом, поскольку наибольший вклад в изменение климата вносят выбросы $\mathrm{CO}_{2}$ от потребляемой электроэнергии. Поэтому выбор альтернативного оборудования 

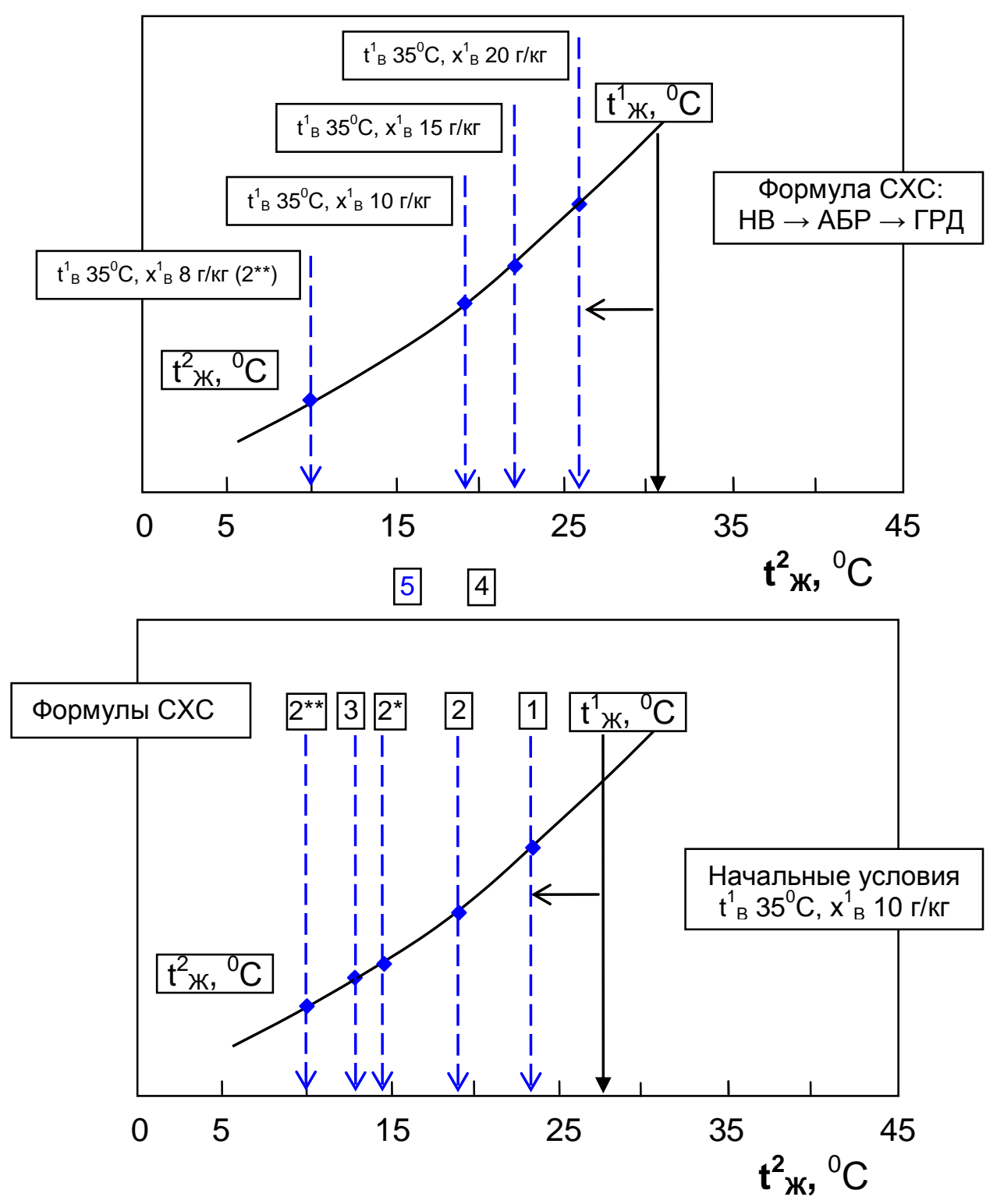

$$
\begin{aligned}
& \text { 1. } \mathrm{HB} \rightarrow \text { ГРД } \\
& \text { 2. } \mathrm{HB} \rightarrow \mathrm{AБP} \rightarrow \text { ГРД; } \\
& \text { 3. } \mathrm{HB} \rightarrow \mathrm{AБP} \rightarrow \mathrm{HИO} \rightarrow \text { ГРД } \\
& 2^{*} \text { и } 2^{* *} . \mathrm{HB} \rightarrow \mathrm{AEP} \rightarrow \text { ГРД }(\mathrm{CXC})
\end{aligned}
$$

Рисунок 7 - Принципиальные возможности (достигаемый уровень охлаждения) разработанных солнечных холодильных систем СХС на основе открытого абсорбционного цикла, основанных на различных формулах солнечной холодильной системы 

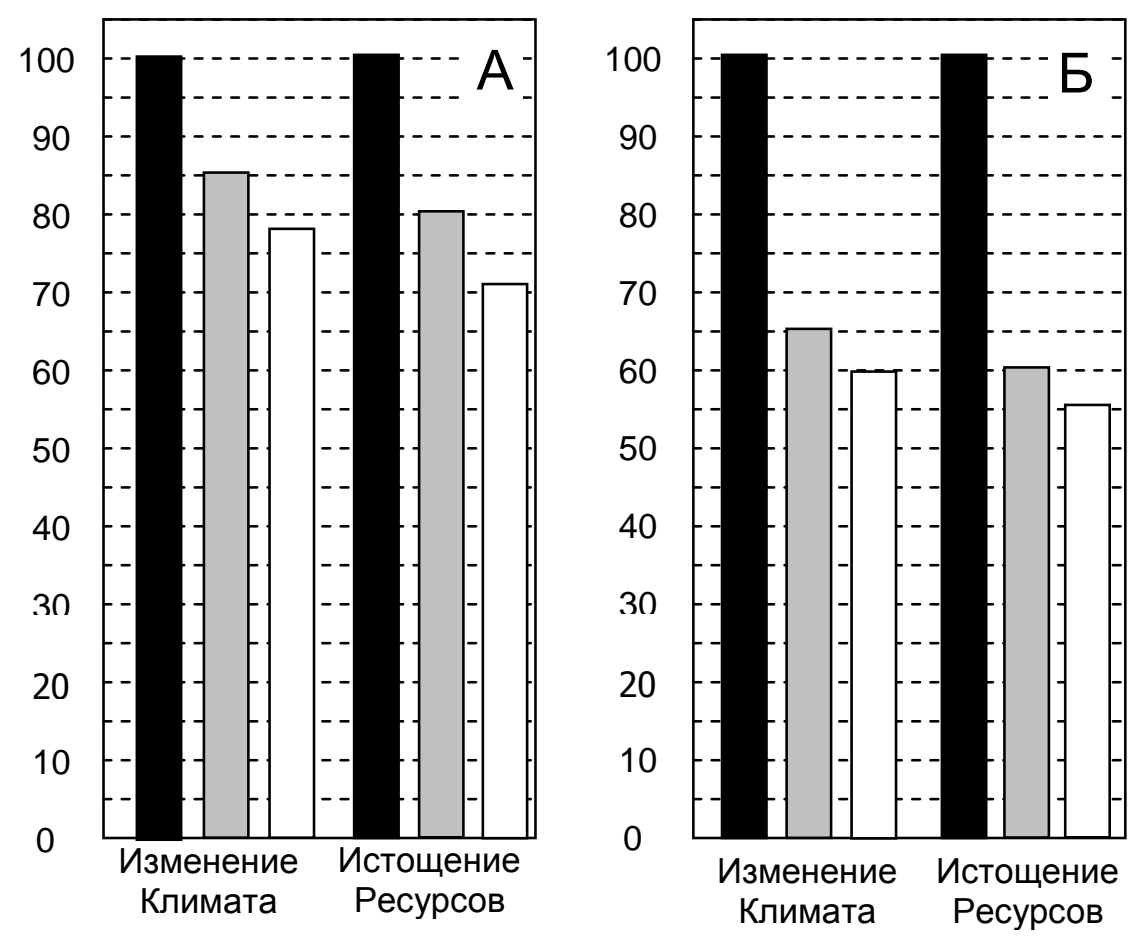

Стадия производства

Стадия эксплуатации
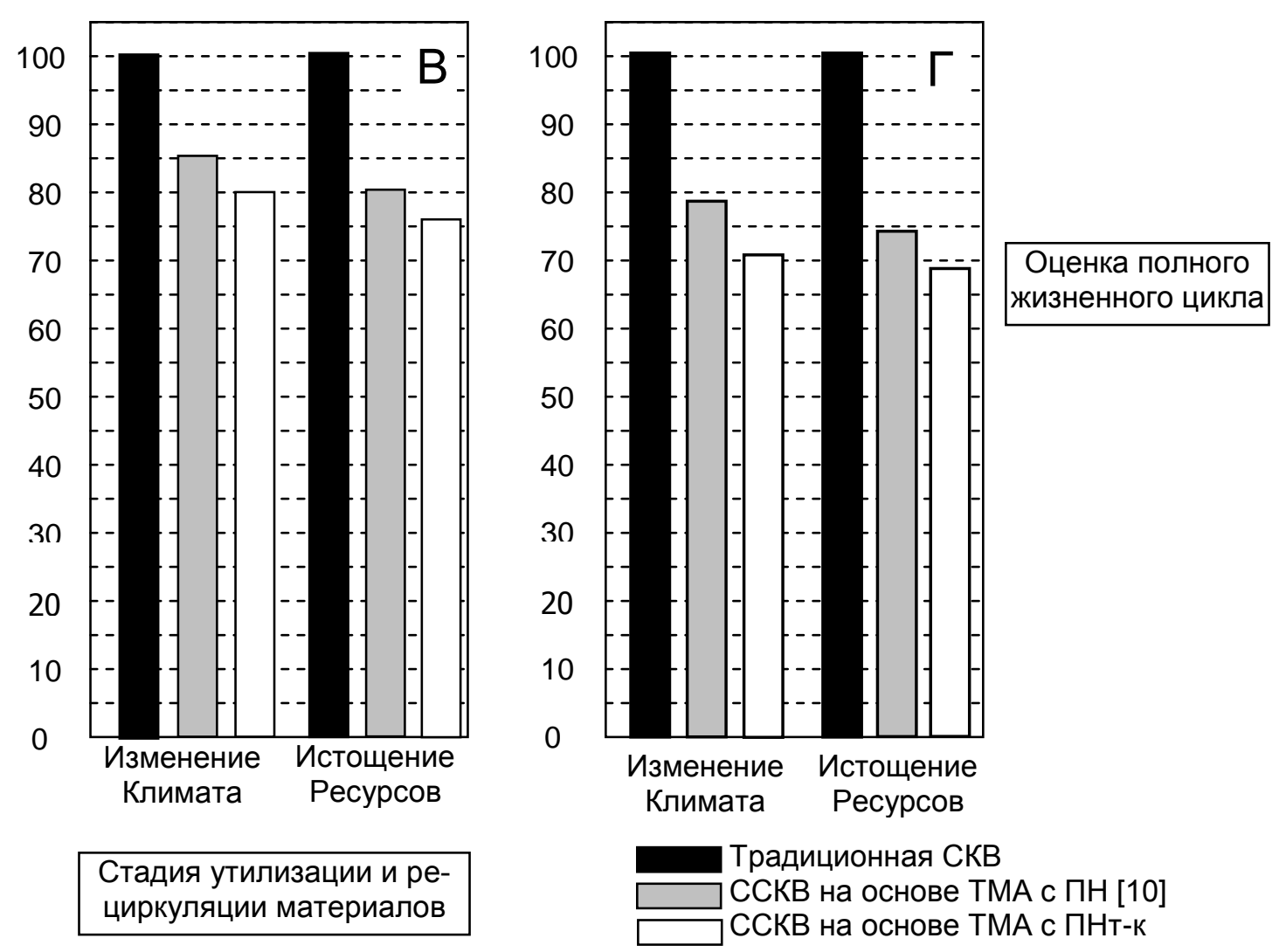

Рисунок $\boldsymbol{8}$ - Сравнение экологического воздействия на стадиях производства (А), в периоды эксплуатации (Б), утилизации (В) и в рамках полного жизненного цикла (Г) для традиционной (парокомпрессионной) СКВ и абсорбционных осушительно-испарительных вариантов ССКВ (на основе ПН и ПНт-к насадочного слоя ТМА). 
по двум анализируемым критериям (влияние на истощение природных ресурсов и вклад в глобальное потепление) будет способствовать реализации закона Украины об энергосбережении и Киотского протокола (направленного на снижение эмиссии парниковых газов). Общее экологическое воздействие для традиционной системы так же больше, чем для альтернативных, что еще раз подтверждает преимущества последних. Полученные результат показывают, что наибольшее воздействие на окружающую среду производится во время эксплуатации систем. Причем наибольшее влияние в этот период связано с энергопотреблением СКВ.

Вариант ССКВ, основанный на использовании насадочных слоев ПНт-к во всех ТМА осушительного и охладительного контуров имеет лучшие показатели по основным позициям «Изменение климата» и «Истощение ресурсов»как сравнительно с традиционной СКВ, так и в сравнении с вариантом солнечной системы с ТМА на основе ПН слоев насадки.

\section{V. ВЫВОДЫ}

1. Разработаны схемные решения солнечных систем на основе открытого абсорбционного цикла с непрямой регенерацией абсорбента и использованием тепломассообменных аппаратов в виде подвижных насадочных слоев «газ-жидкость-твердое тело» в осушительном и охладительном контурах систем; впервые разработаны ТМА с ПН непрямого типа (испарительные охладители НИОг и НИОж, абсорберыосушители и десорберы-регенераторы), что существенно расширяет возможности солнечных холодильных систем (СХС или ССКВ) [12-13];

2. На основе цикла экспериментальных исследований выполнен анализ принципиальных возможностей разработанных ССКВ; солнечная система обеспечивает получение комфортных параметров, при существенной экономии энергии сравнительно с традиционной СКВ на основе парокомпрессионного холодильного агрегата;

3. Разработанный вариант $\mathrm{CXC}^{*}$ с охлаждением абсорбера АБР частью охлажденной в НИОж воды позволяет исключить из схемы осушительного контура градирню технологического назначения ГРДт, обслуживающую абсорбер и снизить температурный уровень процесса абсорбции водяных паров, что ведет к существенному повышению эффективности этого процесса и СХС в целом;

4. Сравнительный эко-энергетический анализ традиционных и альтернативных СКВ показал, что ССКВ, основанная на использовании насадочных слоев ПНт-к во всех ТМА осушительного и охладительного контуров, имеет лучшие показатели по основным позициям «Изменение климата» и «Истощение ресурсов» как сравнительно с традиционной СКВ, так и в сравнении с вариантом солнечной системы с ТМА на основе ПН слоев насадки.

\section{ЛИТЕРАТУРА}

1. Дорошенко А.В., Глауберман М.А. Альтернативная энергетика, Солнечные системы теплохладоснабжения, Одесса, ОНУ им. Мечникова, 2012, $447 \mathrm{c}$.

2. Горин А.Н., Дорошенко А.В., Данько В.П. Тепломасообменные аппараты с подвижной насадкой для традиционных и альтернативных энергетических систем. Донецк, Світ книги, 2013, 327 с.

3. Alexander V. Doroshenko, Leonid P. Kholpanov, Yury P. Kvurt. Alternative Refrigerating, Heat-Pumping and Air-Conditioning Systems on the Basis of the Open Absorption Cycle and Solar Energy. USA. Nova Science Publishers, Inc., 2009. - 210 p.

4. Дорошенко А.В., Филин С.О., Богуслав Закшевский. Evaporative Coolers in Alternative Energetics. Испарительные охладители в альтернативной энергетике, Западно-поморский технологический университет, Щецин, Польша, 2012, 439 с.

5. Doroshenko A., Boris Blyukher. Solar Power Engineering (Theory, Development, Practice), Handbook of Research on Solar Energy Systems and Technologies IGI Global, USA. 2012., 445 p.

6. Grandov A., Doroshenko A., Yatskar I. Cooling Towers with fluidized beds for contaminated environment. Int. J. Refrig, 1995. - Vol. 18, No. 8, pp. 512-517.

7. Sisupalan N., Seetharamu K.N. Heat transfer and pressure drop in fluidized bed cooling tower. Wärme- und Stoffübertragung. 1992. - No. 27. - P. 499-503.

8. Seetharamu K. N., Varier K. V. S. Performance of a fluidized bed cooling of various configuration. Wärmeund Stoffübertragung. - 1988. - No. 22. - P. 219-222.

9. Дорошенко А.В., Молчанский Б.Е. Солнечные системы кондиционирования воздуха осушительноиспарительного типа и тепломасообменной аппаратурой с подвижным трехфазным слоем. Холодильная техника и технология. 2008, № 4 (114), стр. 27-33.

10. Дорошенко А.В., Данько В.П. Теплоиспользующие абсорбционные осушительно-испарительные системы охлаждения с использованием альтернативных источников энергии. Холодильная техника и технология, 2012, №4 (138). - С. 47-53.

11. Дорошенко А.В., Глауберман М.А., Данько В.П. Солнечные осушительно-испарительные холодильные системы на основе тепломассообменных аппаратов с подвижной насадкой. Холодильная техника и технология, 2012, № 6 (140). - С. 22-30.

12.Дорошенко А.В., Гончаренко В.А. Разработка многофункциональных солнечных систем на основе теплоиспользующего абсорбционного цикла и тепломасообменных аппаратов с подвижной насадкой. Холодильная техника и технология, 2015, 51(1).- С.35-46. 13.Дорошенко А.В., Гончаренко В.А., Цапушел А.Н., Демьяненко Ю.И. Экспериментальные исследования гидро-аэродинамики и тепломассообмена в аппаратах с подвижной псевдоожиженной насадкой. Холодильная техника и технология, 2016, 52(1). C. 23-34. 
A. V. Doroshenko ${ }^{\bowtie}$, V. A. Goncharenko, I. Yu. Mladionov, A. N. Tsapushel

Odessa National Academy of Food Technologies, 112 Kanatnaya St., Odessa, 65039, Ukraine

$\triangle$ e-mail: dor_av@i.ua

\section{DEVELOPMENT OF MULTIFUNCTIONAL ABSORBING SOLAR SYSTEMS ON THE BASIS OF FLUIDIZED BED HEAT-MASS-TRANSFER APPARATUS}

The schematics of heat and mass transfer apparatus with the fluidized beds attachment "gas - liquid - solid body" for the evaporative cooling of environments (evaporative coolers of water (cooling towers CTW) and evaporative coolers of air (direct and indirect type coolers IECg and IECw) have been worked out. The multifunction solar refrigeration and air conditioning systems based on absorbing open-cycle with the indirect regeneration of absorbent were designed. In the drainage and cooling contours of solar systems heat and mass transfer apparatus with fluidized beds are utilized. Decisions for heat and mass transfer apparatus with the fluidized beds "gas - liquid - solid body" in a few basic variants, in particular, with possibility of placing of heatexchanger directly in the volume of the fluidized beds have been elaborated, namely: evaporative coolers of air of indirect type (IECg) and evaporative coolers of liquid of indirect type (IECw) of cool contour of the solar systems; absorber-drier of the air flow and desorber-regenerator of absorbent of contour of drainage of outward air of the solar systems. The cycle of experimental researches of fluidizing bed "gas - liquid - solid body" features was executed both for a variant with the free fluidized bed of attachment and in a variant with placing of heat-exchanger directly in the volume of the fluidized bed of attachment. Influence of height of stationary layer of elements, geometrical parameters of distributive grate was studied, initial parameters of current of air, entering in the heat and mass transfer apparatus. On the basis of cycle of theoretical and experimental researches practical recommendations offer on determination of optimal geometrical parameters of basic elements and regime parameters of work of heat and mass transfer apparatus in autonomous behavior and in composition the multifunction solar absorbing systems.

Keywords: Heat and Mass transfer apparatus; Fluidized bed; Evaporative cooler; Cooling tower; Indirect evaporative cooler; Absorber; Desorber (absorbent regenerator); Solar system; Refrigeration system; Air conditioning system.

\section{REFERENCES}

1. Doroshenko, A.V., Glauberman, M.A. (2012). Alternativnaya energetika, Solnechnyie sistemyi teplohladosnabzheniya, Odessa, ONU im. Mechnikova, 447 p.

2. Gorin A.N., Doroshenko, A.V., Danko, V.P. (2013). Teplomassoobmennye apparaty s podvizhnoi nasadkoi dlia traditsionnykh I alternativnykh energeticheskikh sistem. Donetsk, Svit knygy, 327 p.

3. Alexander V. Doroshenko, Leonid P. Kholpanov, Yury P. Kvurt. (2009). Alternative Refrigerating, HeatPumping and Air-Conditioning Systems on the Basis of the Open Absorption Cycle and Solar Energy. USA, Nova Science Publishers Inc., $210 \mathrm{p}$.

4. Doroshenko, A.V., Filin, S.O., Zakshevsky, B. (2012). Evaporative Coolers in Alternative Energetics. Zachodniapomorski Uniwersytet Technologiczny w Szczecinie, Polska, 439 p.

5. Doroshenko, A., Blyukher, B. (2012). Solar Power Engineering (Theory, Development, Practice), Handbook of Research on Solar Energy Systems and Technologies IGI Global, USA, 445 p.

6. Grandov, A., Doroshenko, A., Yatskar, I. (1995). Cooling Towers with fluidized beds for contaminated environment. Int. J. Refrig, 18(8), 512-517.

7. Sisupalan, N., Seetharamu, K.N. (1992). Heat transfer and pressure drop in fluidized bed cooling tower. Wärme- und Stoffübertragung, No. 27, 499-503.

8. Seetharamu, K. N., Varier, K. V. S. (1988). Performance of a fluidized bed cooling of various configuration. Wärme- und Stoffübertragung, No. 22, 219-222.
9. Doroshenko, A.V., Molchansky, B.E. (2008). Solar climatization systems of dranaige-evaporated type and heat-mass exchanging apparatus with a mobile threephase layer. Refrigeration Engineering and Technology, No. 5(115), 27-33.

10. Doroshenko, A.V., Danko, V.P. (2012). Teploispolzuyuschie absorbtsionnyie osushitelnoisparitelnyie sistemyi ohlazhdeniya s ispolzovaniem alternativnyih istochnikov energii. Refrigeration Engineering and Technology, 4(138), 47-53

11. Doroshenko, A.V., Glauberman, M.A., Danko, V.P. (2012). Solnechnyie osushitelno-isparitelnyie holodilnyie sistemyi na osnove teplomassoobmennyih apparatov $\mathrm{s}$ podvizhnoy nasadkoy. Refrigeration Engineering and Technology, 6 (140), 22-30.

12. Doroshenko, A.V., Goncharenko, V.A. (2015). Engineering development of multifunctional solar systems based on the heat-absorption cycle and heat and mass transfer devices with a mobile nozzle. Refrigeration Engineering and Technology, 51(1), 35-46.

doi: 10.15673/0453-8307.1/2015.36783

13. Doroshenko, A.V., Goncharenko, V.A., Tsapushel, A. N., Demianenko, Yu.S. (2016). Experimental researches of heat transfer and pressure drop in fluidized bed cooling tower of various configuration. Refrigeration Engineering and Technology, 52(1), 23-34.

Received 29 February 2016 Approved 03 March 2016 Available in Internet 29 April 2016 